
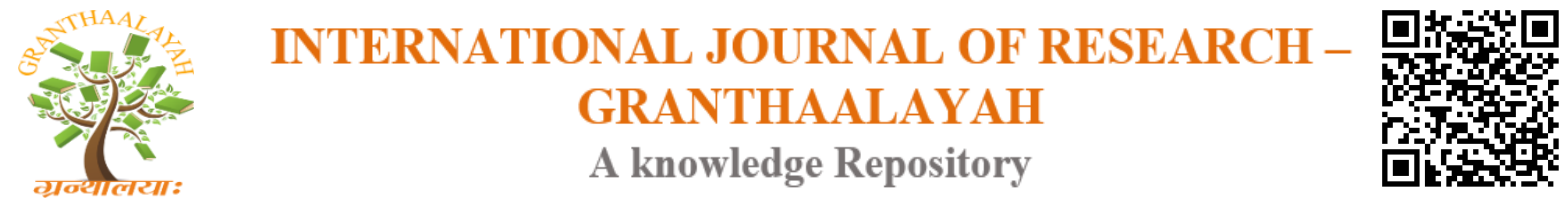

Social

\title{
NATURE EDUCATION TEACHING TECHNIQUES FOR HEARING IMPAIRED PEOPLE
}

\author{
Emre Kuzugudenli ${ }^{* 1}$, Huseyin Goktas ${ }^{1}$, Canpolat Kaya ${ }^{1}$, A.Fatih Kilic ${ }^{2}$ \\ ${ }^{*}$ Forestry Department, Yenisarbademli Vocational Sch., Suleyman Demirel University, Turkey \\ ${ }^{2}$ Educational Sciences, Education Faculty, Suleyman Demirel University, Turkey
}

\begin{abstract}
Nature is one of the most important elements that affect human life positively. Studies conducted up to this time have also revealed the relation of nature to human health and psychology. Nature education activities for people with disabilities come to the fore in recent years. There are various studies in this subject. The aim of the study is to determine this nature education technique for the hearing impaired students. For this purpose, 192 hearing impaired students were given nature education. As a result of the study, interviews were evaluated and nature education techniques for hearing impaired people were determined.
\end{abstract}

Keywords: Hearing Impaired; Nature Education; Nature Themed Techniques.

Cite This Article: Emre Kuzugudenli, Huseyin Goktas, Canpolat Kaya, and A.Fatih Kilic. (2017). "NATURE EDUCATION TEACHING TECHNIQUES FOR HEARING IMPAIRED PEOPLE." International Journal of Research - Granthaalayah, 5(12), 298-301. https://doi.org/10.29121/granthaalayah.v5.i12.2017.506.

\section{Introduction}

The impact of nature on human health is quite excessive. Some scientists argue that living in cities is contrary to human nature, the nature of man must be intertwined with nature. It is thought that the basic sources of diseases originate from life in cities. The close relationship between plant and human begins with the transformation of seed into nutrients. The origins of the use of plants for medical purposes extend back to ancient times. But many studies have proved positive effects on human health of being in the nature and being active or passive in any kind of activities in nature. Many researches show that some special landscape arrangements encourage people to be more comfortable and better [1]. Research that began by defining the relationship between human health and the natural environment [2], and investigated the effects of natural landscaping on human health and psychology [3, 4]

All the positive effects of nature on human health and psychology have revealed the idea that disabled people are more likely to benefit from nature education. With this idea some nature education studies were carried out with various groups of disabled people. Kaya and 
Kuzugudenli (2016) with hearing-impaired group [5]; Kuzugudenli and Kilic (2016) with orthopedic disabled group [6] (2016); and Gulcu and friends (2013), with mentally disabled group [7].

Hearing-impaired people have some difficulties since birth. Namely children learn a lot of information with the help of their hearing skills. Babies can recognize their parent's voices when they are a few weeks old, listen to slow tones and their babbling. Thus, through the hearing senses, they constantly hear the conversation of other people in their surroundings and link these sounds with the events, works and games that occur there. They make sense of these voices and learn that people transmit their thoughts, feelings and knowledge through speaking and hearing. When children began to school, they learned to speak their mother tongue at a level close to adults and they acquired a vast vocabulary. Even when language acquisition is a very complex phenomenon, children learn their mother tongue and speaking very naturally and very quickly. Children with hearing loss cannot learn language without special help. At their best age to learn, they miss these early opportunities because of these obstacles and cannot win their mother tongue [8]. From this group of obstacles, hearing impaired people are separated from other groups of obstacles for reasons such as the fact that their obstacles are not clear and they cannot express themselves exactly.

\section{Materials And Methods}

The data of this research were obtained from hearing impaired students participated in the 4004 TUBITAK nature education called Quiet Nature 1-2-3-4 [9,10,11,12]. A total of 192 hearing impaired elementary school students who were previously selected from different provinces, and who haven't been participated in a similar organization such as training program, seminars, courses, etc. taken to the scenic areas of Isparta (Turkey) and they were trained by, Ecologists, Botanists Zoologists, Geologist and Dramatist academics who are all experts in their fields. In this training, some plants, animals, rock samples have been introduced, and as well as artistic activities such as t-shirt hand painting, marbling techniques, making ornaments by dough, some theatric activities and games were also played.

\section{Results and Discussions}

At the end of the project interviews were held with hearing-impaired students and teachers. These interviews were evaluated with special education specialists and instructors and the following results were obtained for the educator.

- Make your conversation in an environment that can be seen by a hearing-impaired child. This is the image of the lips of the person who speaks in the clearest, most accurate and best way. If the child can see your lips when you speak, he can understand better.

- Keep in mind that a cigarette, a lot of beard and whiskers close the view of the child. Make sure the light is on your lips.

- The student should see the teacher's face and not be spoken while teacher writing the board.

- Teacher always must be on the front.

- Exaggerated lip movements should be avoided without changing the normal speech pattern. 
- These movements should be avoided during the speech because an exaggerated act will dissipate the attention of the student.

- Unhindered students in the group should be explained the hearing disability and be told how they should act against hearing impaired students.

- Do not forget that too noisy environments for the hearing impaired to work will disturb the student and have difficulty distinguishing between speeches. Also when you communicate with the child, give him time to listen and think.

- Try to be calm, loving and consistent.

- Avoid touching unless necessary

\section{Conclusions and Recommendations}

A person with a hearing impairment is someone who has enough hearing impairment to require special education despite the necessary adjustments. Most people with hearing impairments have normal intelligence. Hearing arousal causes learning difficulty, not mental retardation. Hearing impaired especially affecting verbal language acquisition. However, communications have also brought some problems with hearing impairments.

The vocabulary of hearing impaired develops more slowly than the normal hearing. The difference between the normal hearing and hearing impairments in the vocabulary begins with birth, and this difference increases as the age progresses. Hearing impaired children cannot catch their normal hearing peers until they receive special education.

However, hearing impairments reach the same speed and order as normal hearing children during the stage of basic motor development (sitting, crawling, unaided walking etc.). Depending on the cause and severity of hearing loss, balance and general coordination skills are sometimes seen to be in adequate. This disability decreases after using hearing aids and adapting to sounds.

They provide their learning experiences by discovering their surroundings and communicating with other people. They don't make enough use of the audible stimuli when they acquire this information. They have difficulty in perceiving objects, people and events that have sounds. In conclusion, inadequacy of thinking, decision making, and interpreting, evaluating cause-effect relationships is observed.

When describing plant species for the hearing impaired, for example; 'Eastern Spruce is grown extensively as an ornamental plant, especially in Europe, beside the origin country. It is notable for its foliage system, which is dense, dark and polished. Using gardening; young leaves have many valuable forms that first turn yellow, than turn green.' This way a narration is very wrong because hearing impaired people have difficulty in interpreting more than one meaning of the same word. They understand and express simpler and shorter sentences than those of normal hearing. They have difficulty in understanding sentences such as casual and passive sentences. This narration should be; 'Eastern Spruce is the tree of Turkey. There are also in Europe. This tree is in parks in Europe. The leaves are radiant. There are also yellow-green leaves.'

The degree of disability is important in the education of hearing impaired. People who have very light and slight hearing loss should be trained after the necessary arrangements have been made 
in training areas. These arrangements can be listed as being close to the loudspeaker of the lecturer, carrying the sound-transmitting properties of the walls and the places, and minimizing the echoing the sound.

People with severe hearing loss should use sign language and fingerprint alphabets, which are visual communication systems based on describing objects and ideas with signs. Other than these, images such as pictures, graphics and videos can also be used. Because hearing impaired people are unable to use their hearing skills, they have exhibit lack of confidence in their immediate surroundings, such as family members and friends, and thus behave like irritability, introspection, anger. This is why we must be patient, friendly and understanding in our communication with them.

\section{References}

[1] Kaplan, R., \& Kaplan, S. (1989). The experience of nature: A psychological perspective. CUP Archive.

[2] Kellert, S. R., 1998. A National Study of Outdoor Wilderness Experience. New Haven: Yale University School of Forestry and Environmental Studies. p309,

[3] Ulrich, R. S. (2002, April). Health benefits of gardens in hospitals. In Paper for conference, Plants for People International Exhibition Floriade (Vol. 17, No. 5, p. 2010).

[4] Velarde, M. D., Fry, G., \& Tveit, M. (2007). Health effects of viewing landscapes-Landscape types in environmental psychology. Urban Forestry \& Urban Greening, 6(4), 199-212.

[5] Kaya, C., Kuzugüdenli, E., 2016. Nature - Themed Teaching Methods for Deaf Students, Journal of Multidisciplinary Engineering Science and Technology (JMEST). ISSN: 2458-9403, pp.54755478.

[6] Kuzugüdenli, E., Kılıç, A. F., 2015. Doğa Eğitiminin Ortopedik Engelli Bireyler Üzerindeki Etkisi. 24. Ulusal Eğitim Bilimleri Kongresi, Niğde Üniversitesi, Niğde, Turkey. 16-18 Nisan 2015.

[7] Kuzugüdenli, E., Kılıç, A. F., Kaya, C., 2015. Doğa Eğitiminin Bedensel Engelli Bireylerin Sosyal Gelişimine Etkisi. 24. Ulusal Eğitim Bilimleri Kongresi, Niğde Üniversitesi, Niğde,Turkey. 16-18 Nisan 2015.

[8] Avcioğlu, H. (2015). İşitme yetersizliği olan öğrenciler. İbrahim H. Diken (Editör) Özel Eğitime Gereksinimi Olan Öğrenciler ve Özel Eğitim. (s. 168-215). Ankara. Pegem Yayıncılık.

[9] Kaya, C. (2013). Sessiz Doğa 1, TÜBİTAK-4004, Project No: 113B037, Isparta.

[10] Kaya, C. (2014). Sessiz Doğa 2, TÜBİTAK-4004, Project No: 213B713, Isparta.

[11] Kaya, C. (2015). Sessiz Doğa 3, TÜBİTAK-4004, Project No: 115B266, Isparta.

[12] Kaya, C. (2017). Sessiz Doğa 4, TÜBİTAK-4004, Project No: 117B139, Isparta.

*Corresponding author.

E-mail address: emrekuzu@ sdu.edu.tr 